\title{
Examination of the Reading Self-Efficacy of Learners of Turkish as a Foreign Language Regarding Some Variables ${ }^{1}$
}

\section{Gürkan Moralı}

Dr., Erciyes University, Faculty of Education, Turkey, gurkanmorali@gmail.com

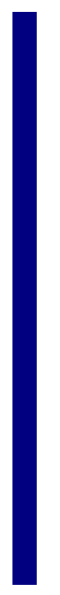

The aim of this research is to examine of Turkish foreign language learners' reading self-efficacy in terms of gender, educational level, Turkish language achievement level, and the number of Turkish books read. The study has the descriptive characteristic. It is designed according to the cross-sectional survey research. The participants of the research are composed of 273 international students. The data were obtained by the personal information form developed by the researcher and "Reading Skill Self-Efficacy Scale for Students Learning Turkish as a Foreign Language" developed by Kan \& Güngör (2015). Independent sample t-test, one-way analysis of variance (ANOVA), Kruskal-Wallis-H, MannWhitney-U and Scheffe tests were applied to analyze the data. As a result of the study, it was found out that there were significant differences in Turkish foreign language learners' reading self-efficacy in terms of educational level, Turkish language level, and the number of Turkish books read. But there was no significant difference in Turkish foreign language learners' reading self-efficacy in terms of gender.

Keywords: reading, reading self-efficacy, Turkish as a foreign language, language learning, foreign language

\section{INTRODUCTION}

Self-efficacy is a term that has been the subject of many studies. It has become popular with Bandura (1977). This concept defines an affective variable used to reflect the selfbelief of the individual regarding performing a task or job (Dörnyei, 1994; Tobing, 2013). It is one of the key concepts within the social cognitive theory (Bandura, 1977; Pajares, 2002).

\footnotetext{
${ }^{1}$ This study is the extended form of the paper presented orally at the conference titled as "Uluslararası Yabancı Dil Öğretimi ve Yabancı Dil Olarak Türkçe Öğretimi Sempozyumu”

Citation: Moral1, G. (2019). Examination of the Reading Self-Efficacy of Learners of Turkish as a Foreign Language Regarding Some Variables. International Journal of Instruction, 12(1), 1445-1458. https://doi.org/10.29333/iji.2019.12192a
} 
Self-efficacy is an effective factor on the behaviors of the individual according to the social cognitive theory (Açıkel, 2011; Kurbanoğlu, 2004). Self-efficacy belief stems from four sources: personal experience (based on success), indirect experiences (based on observation), social persuasions, and physiological and psychological condition (Bandura, 1995). The source that has the most powerful effect on the self-efficacy belief of the individual is the personal experiences based on success (Kotaman, 2008; Kurbanoğlu, 2004; Sakız, 2013). Self-efficacy is a motivating factor for students to be able to perform a task (Tobing, 2013). It plays a significant role in choosing what type of activities they can do (Bandura, 1986).

There are important reflections of Bandura's social cognitive theory on the reading education as on different fields (Ülper, Yaylı \& Karakaya, 2013). Because reading is affected not only by the cognitive processes but also by the affective properties. Selfefficacy is a factor affecting the reading skill of the students. Reading self-efficacy can be defined as a concept reflecting the self-belief of the individual regarding the ability to fulfill reading activities. Self-efficacy being deterministic in behavior choices of individuals (Schunk, 2009), is also an effective factor for student to give effort (Kurbanoğlu, 2004; Sakız, 2013; Schunk, 2009). Considering also the effects of selfefficacy on the behavior choices and giving effort, it can be seen that it has reflections from different angles on the reading process of the individuals. According to Erdem, Altunkaya and Ateş (2017) students with high reading self-efficacy are one step ahead in determining the reading goals and showing performance for achieving these goals. Examining the self-efficacy of foreign language reading provides important findings in reflecting the capacities of the students regarding the reading procedure (Mills, Pajares \& Herron, 2006).

Despite the self-efficacy studies on language learning are relatively limited (Açıkel, 2011; Raoofi, Tan \& Chan, 2012) it can be seen that different variables are handled in the studies related to the foreign language learning. In these studies, it is determined that reading self-efficacy is examined based on different variables like reading concern, reading strategy usage, understanding own reading, reading competence (Ghonsooly \& Elahi, 2010; Li \& Wang, 2010; Mills, Pajares \& Herron, 2006; Naseri \& Zaferanieh, 2012). Ghonsooly and Elahi (2010) has studied the relation between the reading selfefficacy and the reading concern and determined a significant negative correlation between two variables. Li and Wang (2010), Naseri and Zaferanieh (2012) whereas, reached the result that there is a positive relationship between reading self-efficacy belief and reading strategy usage. Mills, Pajares and Herron (2006) indicated that there is a positive relation between reading self-efficacy and the reading competence of the students. Naseri and Zaferanieh (2012) presented that there is a strong positive relation between reading self-efficacy and understanding own reading. According to Tobing (2013), there were positive correlation in most of studies related with reading ability and self-efficacy in teaching English as a foreign language (EFL).

The studies regarding the reading self-efficacy are at the initial stage in Turkish foreign language (TFL) context. Similarly, studies on reading self-efficacy are limited in EFL literature (Tobing, 2013). However, the role of self-efficacy in teaching TFL field has 
not been widely studied. In this area, Erdem, Altunkaya and Ateş (2017) have studied the reading self-efficacy of international students at upper-intermediate level called B2 under the scope of gender, age, known language number, Turkish learning time variables.

The self-efficacy belief efficient in the learning of TFL is a factor subjected to various studies in TFL context (Altunkaya \& Ateş, 2017; Aydın et al., 2017; Büyükikiz, 2011; Erdem, Altunkaya \& Ateş, 2017; Erdil, 2017; Kurudayığlu \& Güngör, 2017; Sallabaş, 2012). In these studies the self-efficacy is generally handled in the frame of speaking (Aydın et al., 2017; Kurudayığlu \& Güngör, 2017; Sallabaş, 2012), reading (Erdem, Altunkaya \& Ateş, 2017) and writing (Altunkaya \& Ateş, 2017; Büyükikiz, 2011; Erdil, 2017) skills. In these studies gender (Altunkaya \& Ateş, 2017; Aydın, Şahin, Yağmur Şahin, Emre \& Sal1, 2017; Büyükikiz, 2011; Erdil, 2017; Kurudayığlu \& Güngör; 2017; Sallabaş, 2012), Turkish language levels (Erdil, 2017; Kurudayığlu \& Güngör; 2017), age (Altunkaya \& Ateş, 2017; Büyükikiz, 2011; Erdil, 2017; Kurudayığlu \& Güngör; 2017), Turkish book reading (Altunkaya \& Ateş, 2017; Büyükikiz, 2011; Sallabaş, 2012), continent/student regions (Erdil, 2017; Kurudayığlu \& Güngör; 2017; Sallabaş, 2012), the number of other foreign languages known (Aydın et al., 2017; Büyükikiz, 2011), receiving Turkish training previously (Büyükikiz, 2011; Sallabaş, 2012), the institution of Turkish learning (Kurudayığlu \& Güngör; 2017), Turkish language hardness perception (Büyükikiz, 2011; Sallabaş, 2012), Turkish television watching (Büyükikiz, 2011; Sallabaş, 2012), aim of learning Turkish (Büyükikiz, 2011; Sallabaş, 2012), Turkish learning time (Kurudayığlu \& Güngör; 2017) and time spent in Turkey (Büyükikiz, 2011; Sallabaş, 2012) are examined as variables. While most of the studies related to self-efficacy were directed to different skills of language, the number of studies related to self-efficacy was not sufficient in the literature. In particular, it is realized that there is a gap in the literature for the study of variables affecting reading self-efficacy. For this reason, this study aims to examine the reading self-efficacy of the international students learning Turkish as a foreign language regarding gender, educational level, Turkish language achievement level, and number of Turkish books read in a year variables. These variables are chosen as they are the variables frequently considered in the studies related with the self-efficacy in TFL context. The following questions are tried to be answered:

1. What are the levels of reading self-efficacy of international students?

2. Is there a significant difference in reading self-efficacy scores of the students regarding educational level?

3. Is there a significant difference in reading self-efficacy scores of the students regarding gender?

4. Is there a significant difference in reading self-efficacy scores of the students regarding Turkish language achievement level?

5. Is there a significant difference in reading self-efficacy scores of the students regarding the number of Turkish books read in a year? 


\section{METHOD}

\section{Research Design}

This descriptive research is designed and conducted according to survey model. The reason of studying with this research model is that among the methods to be used to determine the beliefs of the individuals participating in the research regarding their reading self-efficacy survey research is shown (Christensen, Johnson \& Turner, 2015). This research is a cross-sectional study because the data is gathered from the participants in a short period of time and in a single session (Christensen, Johnson \& Turner, 2015).

\section{Participants}

In the research population, there are total of 629 international students studying in high school and university. There are 273 students in the sample of the study via simple random sampling. The number of students in the study sample is enough to represent the population.

145 of the students within the study are attending Kocasinan Mustafa Germirli Anatolian İmam Hatip High School, 128 of same are attending Erciyes University. When the gender distribution of the students is considered there are 247 males and 26 females. 143 of the students came from Asia, 109 from Africa, 17 from Europe and 5 from South America. Their Turkish language levels vary. 75 students are at intermediate level called B1, 86 students at upper-intermediate level called B2 and 112 students at advanced level called $\mathrm{C} 1$. The language levels of the students in the preparatory classes of Erciyes University ERSEM are determined according to their course examination scores and the level of the classes they are attending. The language levels of the high school students are determined according to their class levels, the Turkish course books they follow and the information taken from their teachers. Also, in order to confirm this information by the students, items for determination of language levels are added to the personal information forms.

\section{Instruments}

In this study two data collection tools are used. For gathering the personal information of the students personal information form developed by the researcher is utilized. In the research the "Self-efficacy scale on reading skill for the students learning Turkish as a foreign language" developed by Kan and Güngör (2015), who also tested the validity and reliability of the instrument was used. As the result of the data gathered from 202 international students at B1, B2 and C1 levels, this single dimension scale with Cronbach alpha coefficient .94 and item factor loads change in range .702 to .883 is determined as a valid and reliable tool (Kan \& Güngör, 2015). The scale consists of 16 items. All items composed of positive statements showing international students' can do abilities in Turkish reading skill. The scores between 0-53.3 show low, between 53.4106.7 medium, between 106.8-160 high degrees of reading self-efficacy of the participants. The original language of the scale is Turkish. International students whose 
language levels ranging from $\mathrm{B} 1$ to $\mathrm{C} 1$ can understand the scale in the original language (Kan \& Güngör, 2015). For this reason, the scale was applied in Turkish.

As the current study is performed on a different sample the factor structure of the scale is analyzed via conforming factor analysis (CFA). However in order for the CFA to be performed some assumptions should be met. In this regard, the missing and outlier data analysis of the data set acquired by scale application is realized, and the single and multiple distributions of the data are examined. As the data of 18 students are found, regarding the Mahalonobis distance value, higher than the chi square value (39.252) related to the 16 degrees of freedom, they are determined as outliers and separated from the data set of the research (Tabachnick \& Fidell, 2013). The remaining 273 student data were analyzed. The standardized path coefficients reached as the result of conforming factor analysis of the scale used as the fundamental data gathering tool in the research are shown below.

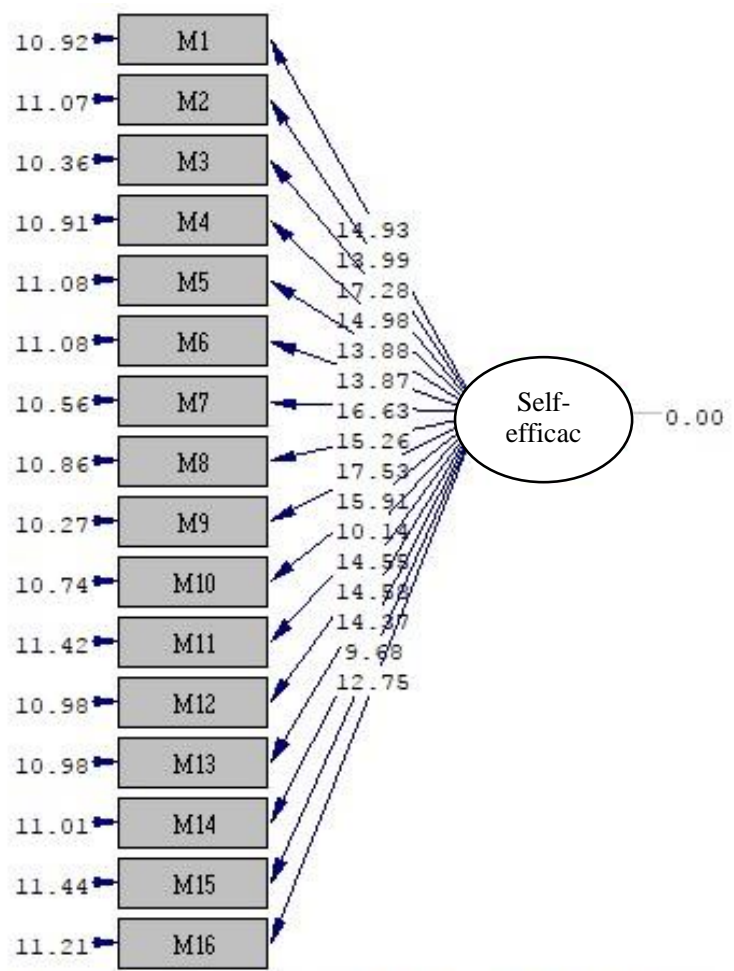

Chi-Square $=349.05, d f=104, \mathrm{P}-\mathrm{value}=0.00000, \mathrm{RMSEA}=0.093$

Figure 1

"Self-efficacy scale on reading skill for the students learning Turkish as a foreign language" CFA standardized path coefficients 
As the $t$ values of these standardized path coefficients are larger than 2.56 the standard value of the path coefficients is found significant at .01 level. The fit indices are shown in Table 1.

Table 1

"Self-efficacy scale on reading skill for the students learning Turkish as a foreign language" CFA fits Indices

\begin{tabular}{llll}
\hline Model fit indices & Value & Good fit & Acceptable fit \\
\hline CFI & .98 & $.95 \leq$ CFI $\leq 1.00$ & $.90 \leq$ CFI $\leq .95$ \\
NNFI & .98 & $.95 \leq$ NNFI $\leq 1.00$ & $.90 \leq$ NNFI $\leq .95$ \\
RMSEA & .093 & $.00 \leq$ RMSEA $\leq .05$ & $.05 \leq$ RMSEA $\leq .10$ \\
SRMR & .043 & $.00 \leq$ SRMR $\leq .05$ & $.05 \leq$ SRMR $\leq .10$ \\
\hline
\end{tabular}

References: Byrne, 2001; Hu \& Bentler, 1999; Klem, 2000; Kline,2005; McDonald

\& Ho, 2002; Schreiber vd., 2006; Şimşek, 2007

Having CFI, NNFI and SRMR in good fit, and RMSEA in acceptable fit ranges shows that the model-data fit is good (Byrne, 2001; Hu \& Bentler, 1999; Klem, 2000; Kline,2005; McDonald \& Ho, 2002; Schreiber et al., 2006; Şimşek, 2007). The Cronbach alpha reliability coefficient calculated in the scope of this research is found as .95 and the reliability of the data collected from the scale is found high (Alpar, 2012).

\section{Data analysis}

Firstly, normality of both data sets of high school and university students is checked. As shown in the Table 1, due to fact that skewness and kurtosis of the both data sets are in the range of -1.5 and +1.5 (Tabachnick \& Fidell, 2013), normal distributions are assumed. Therefore, t-test for independent groups is used in the school level analysis and one-way ANOVA test is used in Turkish level data analysis. In order to determine the differences between groups Scheffe are applied.

Table 2

Descriptive statistic of reading self-efficacy scores of the high school and university students

\begin{tabular}{llllll}
\hline Variables & $\mathrm{n}$ & Mean rank & sd & Skewness & Kurtosis \\
\hline High school & 145 & 131.7034 & 20.05795 & -1.033 & 1.135 \\
University & 128 & 114.8750 & 19.88669 & .123 & -.560 \\
\hline
\end{tabular}

In the gender based data analysis, as the female student number is below 30 , nonparametric statistics is applied and Mann Whitney U-Test is preferred. In number of books read data analysis, as the number of students not reading books is 12 , nonparametric statistics is applied and as there are four unrelated samples Kruskal Wallis $\mathrm{H}$ Test is preferred. In order to determine the differences between groups Mann Whitney U are applied. The data is analyzed using SPPS 16.0 package program.

\section{FINDINGS}

In this section, the results achieved under the scope of the research questions are given via tables. In the table below the results reflecting the levels of reading self-efficacy of the international students are shown. 
Table 3

The levels of reading self-efficacy of international students

\begin{tabular}{llllll}
\hline International students & $\mathrm{n}$ & $\overline{\mathbf{X}}$ & $\mathrm{Sd}$ & $\max$ & $\min$ \\
\hline High school students & 145 & 131.70 & 20.05 & 160 & 67 \\
University students & 128 & 114.87 & 19.88 & 160 & 71 \\
\hline
\end{tabular}

The levels of reading self-efficacy of the international students show a difference. The level of reading self-efficacy of the high school students $(\overline{\mathbf{X}}=131.70)$ shows high degree. The level of reading self-efficacy of the university students $(\bar{X}=114.87)$ shows also high degree. In Table 4 the findings reflecting the reading self-efficacy of the international students regarding the educational level variable are shown.

Table 4

Independent sample t-test results of reading self-efficacy scores according to educational level

\begin{tabular}{lllllll}
\hline Educational Level & $\mathrm{n}$ & $\overline{\mathbf{X}}$ & $\mathrm{sd}$ & $\mathrm{df}$ & $\mathrm{t}$ & $\mathrm{p}$ \\
\hline High school & 145 & 131.70 & 20.05 & 271 & 6.94 & .000 \\
University & 128 & 114.87 & 19.88 & & & \\
\hline
\end{tabular}

The reading self-efficacy of the international students show a significant difference according to educational level, $\mathrm{t}(271)=6.94, \mathrm{p}<.05$. The reading self-efficacy of the high school students $(\overline{\mathbf{X}}=131.70)$ is higher compared to the university students $(\overline{\mathbf{X}}=114.87)$. In Table 5 the findings reflecting the reading self-efficacy of the international students regarding the gender level variable are shown.

Table 5

Mann Whitney U-test results of reading self-efficacy scores of university students according to gender

\begin{tabular}{lllll}
\hline Gender & $\mathrm{n}$ & Mean rank & $\mathrm{U}$ & $\mathrm{p}$ \\
\hline Male & 102 & 62.78 & 1501.500 & 0.298 \\
Female & 26 & 71.25 & & \\
\hline
\end{tabular}

The reading self-efficacy of the university students does not show a significant difference according to gender, $\mathrm{U}=1501.500, \mathrm{p}>.05$. With this finding, it is determined that the gender is not an effective variable in the reading self-efficacy of the international students. The reading self-efficacy scores of high school students according to gender has not calculated. Because this group is only consisted of male students. In Table 6, Table 7 and Table 8 the findings reflecting the reading self-efficacy of the international students regarding Turkish language achievement level variable are shown. 
Table 6

Descriptive statistics of reading self-efficacy scores according to Turkish language achievement level

\begin{tabular}{lllll}
\hline International Students & $\begin{array}{l}\text { Turkish Language } \\
\text { Achievement Level }\end{array}$ & $\mathrm{n}$ & $\overline{\mathbf{X}}$ & sd \\
& B1 & 47 & 130.55 & 17.35 \\
High school students & B2 & 41 & 124.17 & 24.05 \\
& C1 & 57 & 138.07 & 17.02 \\
\multirow{3}{*}{ University students } & B1 & 28 & 108 & 18.85 \\
& B2 & 45 & 112.40 & 20.74 \\
& C1 & 55 & 120.40 & 18.46 \\
\hline
\end{tabular}

Table 7

ANOVA results of reading self-efficacy scores of high school students according to Turkish language achievement level

\begin{tabular}{lllllll}
\hline $\begin{array}{l}\text { Source of } \\
\text { variation }\end{array}$ & Sum of squares & $\mathrm{df}$ & $\begin{array}{l}\text { Mean } \\
\text { squares }\end{array}$ & $\mathrm{F}$ & $\mathrm{p}$ & $\begin{array}{l}\text { Significant } \\
\text { difference }\end{array}$ \\
\hline Between groups & 4699.107 & 2 & 2349.554 & 6.267 & .002 & C1-B2 \\
$\begin{array}{l}\text { Within-group } \\
\text { Total }\end{array}$ & $\begin{array}{l}53235.141 \\
57934.248\end{array}$ & 142 & 374.895 & & & \\
\hline
\end{tabular}

The reading self-efficacy of the high school students show a significant difference according to Turkish language level, $\mathrm{F}(2,142)=6.267, \mathrm{p}<.05$. The reading self-efficacy of the high school students varies according to the Turkish language achievement level. In order to determine between which groups the differences incurring according to the Turkish language achievement level, Scheffe tests results should be seen. According to the results of the Scheffe test, it is found out that the reading self-efficacy of the students in $\mathrm{C} 1$ level is higher compared to ones in B2 level.

Table 8

Kruskal Wallis test results of reading self-efficacy scores of university students according to Turkish language achievement level

\begin{tabular}{llllllll}
\hline Group & $\begin{array}{l}\text { Turkish language } \\
\text { achievement level }\end{array}$ & $\mathrm{n}$ & $\begin{array}{l}\text { Mean } \\
\text { squares }\end{array}$ & df & $\chi^{2}$ & $\mathrm{p}$ & $\begin{array}{l}\text { Significant } \\
\text { difference }\end{array}$ \\
\hline $\mathrm{A}$ & $\mathrm{B} 1$ & 28 & 51.41 & 2 & 10.42 & .005 & C-A, C-B \\
$\mathrm{B}$ & $\mathrm{B} 2$ & 45 & 58.16 & & & & \\
$\mathrm{C}$ & C1 & 55 & 76.35 & & & & \\
\hline
\end{tabular}

The reading self-efficacy of the university students show a significant difference according to Turkish language achievement level, $x^{2}(\mathrm{sd}=2, \mathrm{n}=128)=10.42, \mathrm{p}<.05$. The self-efficacy of the students varies according to Turkish language achievement level. In order to determine between which groups the differences incurring according to the Turkish language achievement level Mann Whitney U results should be seen. According to the results of the Mann Whitney $U$ test the reading self-efficacy of the university students whose Turkish language levels are $\mathrm{C} 1$ is higher than the students whose Turkish language levels are B1 and B2. In Table 9 the findings reflecting the reading self- 
efficacy of the international students regarding the books read in a year variable are shown.

Table 9

Kruskal Wallis test results of reading self-efficacy scores according to number of Turkish books read in a year

\begin{tabular}{lllllllll}
\hline $\begin{array}{l}\text { Internationa } \\
1 \text { Students }\end{array}$ & Group & $\begin{array}{l}\text { Number of } \\
\text { Turkish books } \\
\text { read in a year }\end{array}$ & $\mathrm{n}$ & $\begin{array}{l}\text { Mean } \\
\text { squares }\end{array}$ & $\mathrm{df}$ & $\begin{array}{c}2 \\
\chi\end{array}$ & $\mathrm{p}$ & $\begin{array}{l}\text { Significant } \\
\text { difference }\end{array}$ \\
\hline High school & $\mathrm{A}$ & $1-5$ & 49 & 51.53 & 2 & 20.99 & .000 & A-B, A-C \\
students & $\mathrm{B}$ & $6-10$ & 49 & 78.58 & & & & \\
& $\mathrm{C}$ & 11 and above & 47 & 89.56 & & & & \\
University & $\mathrm{A}$ & $1-5$ & 74 & 61.03 & 2 & 7.77 & .020 & A-C, B-C \\
students & $\mathrm{B}$ & $\mathrm{6}-10$ & 37 & 60.72 & & & & \\
\hline
\end{tabular}

The reading self-efficacy of the high school students show a significant difference according to the number of Turkish books read in a year, $x^{2}(\mathrm{sd}=2, \mathrm{n}=145)=20.99, \mathrm{p}<.05$. Also the reading self-efficacy of the university school students show a significant difference according to the number of Turkish books read in a year, $x^{2}(\mathrm{sd}=2$, $\mathrm{n}=128)=7.77, \mathrm{p}<.05$. The self-efficacy of the students varies according to the number of the Turkish books they read in a year. In order to determine between which groups the differences incurring according to the number of Turkish books read Mann Whitney U test result should be seen. According to the results of the Mann Whitney U test the reading self-efficacy of the high school students who read 6-10, 11 and above is higher than the students who read 1-5 Turkish books in a year. The reading self-efficacy of the university students who read 11 and above is higher than the students who read 1-5 and 6-10 Turkish books in a year.

\section{DISCUSSION}

In this study, the reading self-efficacy of the international students are examined regarding the gender, educational level, language achievement level, and number of Turkish books read in a year variables and some results are reached.

Gender is seen to be an important parameter to be considered in the studies of selfefficacy (Mills, Pajares \& Herron, 2006). In this research, it is determined that there is no significant difference occurring in the reading self-efficacy of the students learning TFL according to gender. This result acquired is contradictory to the study of Erdem, Altunkaya and Ateş (2017) where they determined the gender creates a significant difference in the reading self-efficacy of the students at B level learning Turkish as a foreign language. It is thought that the female participant number being low could be effective in the reading self-efficacy not showing a significant difference according to gender. The high school where the application is made being an only male school and the high school students having higher self-efficacy compared to the students in university could also have affected the gender factor. Because the female count in the studies where Erdem, Altunkaya and Ateş (2017) have reached a significant difference is 72 and the male count is 65 . Having male and female numbers close to each other 
provides an advantage in determining the differences between females and males. Also the result reached regarding the gender variable shows similarities with the self-efficacy studies conducted regarding other language skills in the literature. Aydin et al. (2017), Kurudayığlu and Güngör (2017), Sallabaş (2012) regarding speaking self-efficacies; Altunkaya and Ateş (2017), Büyükikiz (2011), Erdil (2017) regarding writing selfefficacies, have determined that the gender does not show a significant difference. A reading self-efficacy is examined in the scope of this research, there can be a question mark for it to show similarities with the studies handling writing and speaking selfefficacies. However, while reading is assessed separately from speaking and writing as being understanding skill, it can show similarities with speaking and writing due to its aspect of being a fundamental language skill.

It is seen that there is a significant difference in the reading self-efficacies of the international students according to the educational level. The reading self-efficacies of the high school students are higher. It is thought that this condition occurs due to the high school students having spent more time in Turkey, as they have higher course intensity, as they learn Turkish not as training but within school curriculum, in a denser, systemic and longer period. However this result reached is contradictory to the findings in the study of Erdil (2017). Erdil (2017) could not determine a significant difference between the self-efficacies of the students in high school and pre-high school and the students in universities regarding their educational status.

It is determined that there is a significant difference in reading self-efficacies of the international students according to the Turkish language achievement level. This finding shows that there is a relation between the Turkish language achievement level and the reading self-efficacy. As the language achievement levels of the students improve their competence perception for reading increases. This condition is especially apparent in $\mathrm{C} 1$ and B2 levels. This finding show differences with several self-efficacy studies performed regarding various language skills. Kurudayığlu and Güngör (2017) could not determine a significant difference between the language levels and speaking selfefficacies of the ones learning Turkish as a foreign language. Erdil (2017) and Polatcan (2016) indicated that there is no significant difference between writing self-efficacies and Turkish language levels of the international students learning Turkish.

It is determined that there is a significant difference occurring for the international students in reading self-efficacies regarding the number of Turkish books read in a year. There might be a relation between the number of Turkish books read in a year and the reading self-efficacy. International students reading more Turkish books might be considered to have higher reading self-efficacy. The results reached here both contradicts and show similarities with the results reached by Büyükikiz (2011) and Sallabaş (2012). Sallabaş (2012) determined that reading books have no significant effect on speaking self-efficacy but speaking efficacies of the ones reading books is higher than the ones that do not read. Büyükikiz (2011) found out a similar result on writing. 


\section{CONCLUSION}

In this research, it is determined that there is no significant difference occurring in the reading self-efficacy of the international students learning TFL in terms of the gender. It is seen that there is a significant difference in the reading self-efficacies of the international students according to educational level. The reading self-efficacies of the high school students found higher. It is determined that there is a significant difference in reading self-efficacies of the international students in terms of the Turkish language achievement level. It is also found that there is a significant difference occurring for the international students in reading self-efficacies in terms of the number of Turkish books read in a year.

\section{SUGGESTION}

Considering the suggestion presented in line with the results achieved can contribute to the improvement of the reading self-efficacies of the international students and to the literature. The number of Turkish books read creates a significant difference in the reading self-efficacies of the international student, thus students should be provided to read Turkish books proper to their language levels at each course level and it should be checked regularly whether these books are read. Again based on the results achieved in the research, it should be provided that the international students read at least 11 Turkish books before completing $\mathrm{C} 1$ level Turkish course.

\section{ACKNOWLEDGEMENT}

To apply the reading self-efficacy scale in the Kayseri province Kocasinan Mustafa Germirli Anatolian İmam Hatip High School, Province National Education Directorate was applied to for the research permit. I would like to thank the Province National Education Directorate for the permit. Also I would like to thank the ERSEM for the research permit.

\section{REFERENCES}

Açıkel, M. (2011). Language learning strategies and self-efficacy beliefs as predictors of English proficiency in a language preparatory school (Master's thesis). Ankara: Middle East Technical University in Ankara.

Alpar, R. (2012). Uygulamall istatistik ve geçerlik-güvenirlik (2 ${ }^{\text {nd }}$ ed.). Ankara: Detay Yayıncilık.

Altunkaya, H., \& Ateş, A. (2017). The Relationship Between Writing Self-Efficacy and Writing Skills of Turkish Learners as a Foreign Language. Erzincan University Journal of Education Faculty, 19(3), 86-103.

Aydın, G., Şahin, A., Yağmur Şahin, E., Emre, K., \& Salı, M. K. (2017). Yabancı Dil Olarak Türkçe Öğrenenlerin Konuşma Öz Yeterliliklerinin Belirlenmesi (ÇOMÜ TÖMER Örneği). Journal of Awareness, 2(3S), 549-564. 
Bandura, A. (1977). Self-efficacy: Toward a Unifying Theory of Behavioral Change. Psychological Review, 84(2), 191-215.

Bandura, A. (1986). Social foundations of thought and action: A social cognitive theory. New Jersey: Prentice-Hall.

Bandura, A. (1995). Exercise of personal and collective efficacy in changing societies. In A. Bandura (Ed.), Self-efficacy in changing societies (pp. 1-45). Cambridge: Cambridge University.

Büyükikiz, K. (2011). Türkçeyi yabancı dil olarak ögrenenlerin yazma becerileri ile öz yeterlilik algıları arasındaki iliş̧ki üzerine bir araş̧ırma (Doctoral dissertation). Ankara: Gazi University in Ankara.

Byrne, B. M. (2001). Structural equation modeling with AMOS. Mahwah, NJ: Lawrence Erlbaum.

Christensen, L. B., Johnson, R. B., \& Turner, L. A. (2015). Araştırma yöntemleri desen ve analiz (A. Aypay, Çev. ed.). Ankara: Anı Yayıncılık.

Dörnyei, Z. (1994). Motivation and Motivating in the Foreign Language Classroom. The Modern Language Journal, 78(3), 273-284.

Erdem, İ., Altunkaya, H., \& Ateş, A. (2017). Relation Between the Literacy SelfEfficacy and the Ability of Reading Comprehension of Those Who Learn Turkish as a Foreign Language. International Journal of Language Academy, 5(4), 74-86.

Erdil, M. (2017). The Foreign Students' Perception of Self-Competency Towards Turkish Writing Skill. Turkophone, 4(2), 87-101.

Ghonsooly, B., \& Elahi, M. (2010). Learners' Self-Efficacy in Reading and Its Relation to Foreign Language Reading Anxiety and Reading Achievement. Journal of English Language Teaching and Learning, 53(217), 45-67.

Hu, L., \& Bentler, P. M. (1999). Cutoff Criteria for Fit Indices in Covariance Structure Analysis: Conventional Criteria Versus New Alternatives. Structural Equation Modeling, 6, 1-55.

Kan, A. ve Güngör, H. (2015). Yabanc1 Dil Olarak Türkçe Öğrenen Öğrencilere Yönelik Okuma Becerisi Özyeterlik Ölçeği Geliştirme Çalışması. 8. Uluslararası Türkçenin Ĕgitimi Öğretimi Kurultayı Bildiri Özetleri Kitabı içinde (s. 9). Basım Yeri Belirtilmemiş.

Klem, L. (2000). Structural equation modeling. In L. G. Grimm, \& P. R. Yarnold (Eds.), Reading and understanding more multivariate statistics (pp. 227-260). Washington, DC. 
Kline, R. B. (2005). Principles and practice of structural equation modeling ( $2^{\text {nd }}$ ed.). New York: Guilford Press.

Kotaman, H. (2008). Özyeterlilik İnancı ve Öğrenme Performansının Geliştirilmesine İlişkin Yazın Taraması. Uludă̆ Üniversitesi Ĕ̆itim Fakültesi Dergisi, 21(1), 111-133.

Kurbanoğlu, S. S. (2004). Öz-Yeterlik İnancı ve Bilgi Profesyonelleri İçin Önemi. Bilgi Dünyast, 5(2), 137-152.

Kurudayığlu, M., \& Güngör, H. (2017). The Study of Speaking Skills Self-Efficacy of Turkish Learners as a Foreign Language in Terms of Various Parameters. International Journal of Turkish Literature Culture Education, 6(2), 1105-1121.

Li, Y., \& Wang, C. (2010). An Empirical Study of Reading Self-Efficacy and the Use of Reading Strategies in the Chinese EFL Context. Asian EFL Journal, 12(2), 144-162.

Mcdonald, R. P., \& Ho, M-H. R. (2002). Principles and practice in reporting structural equation analyses. Psychological Methods, 7, 64-82.

Mills, N., Pajares, F., \& Herron, C. (2006). A Reevaluation of the Role of Anxiety: Self Efficacy, Anxiety, and Their Relation to Reading and Listening Proficiency. Foreign Language Annals, 39(2), 276-295.

Naseri, M., \& Zaferanieh, E. (2012). The Relationship Between Reading Self-Efficacy Beliefs, Reading Strategy Use and Reading Comprehension Level of Iranian EFL Learners. World Journal of Education, 2(2), 64-75.

Pajares, F. (2002). Overview of social cognitive theory and of self-efficacy. Retreived August 3, 2017, from http://www.emory.edu/EDUCATION/mfp/eff.html

Polatcan, F. (2016). Investigation of Writing Anxiety for Learners of Turkish as a Foreign Language. Route Educational and Social Science Journal, 3(3), 1-13.

Raoofi, S., Tan, B. H., \& Chan, S. H. (2012). Self-efficacy in second/foreign language learning contexts. English Language Teaching, 5(11), 60-73. Retrieved from ERIC database. (EJ1080058)

Sak1z, G. (2013). Key word in success: Self-efficacy. Journal of Uludag University Faculty of Education, 26(1), 185-209.

Sallabaş, M. E. (2012). Assessment of Self-Efficacies of Learners of Turkish as a Foreign Language. The Journal of Turkish Social Research, 16(2), 269-290.

Schreiber, J. B., Stage, F. K., King, J., Nora, A., \& Barlow, E. A. (2006). Reporting Structural Equation Modeling and Confirmatory Factor Analysis Results: A review. Journal of Educational Research, 99(6). 323-337. DOI: 10.3200/JOER.99.6.323-338.

Schunk, D. H. (2009). Öğrenme teorileri ĕgitimsel bir bakışla (M. Şahin, Çev. ed.). Ankara: Nobel Yayıncılık. 
Şimşek, Ö. F. (2007). Yapısal eşitlik modellemesine giriş: Temel ilkeler ve LISREL uygulamaları. Ankara: Ekinoks Yayınları.

Tabachnick, B. G., \& Fidell, L. S. (2013). Using multivariate statistics (6 ${ }^{\text {th }}$ ed.). Boston, MA: Pearson Education.

Tobing, I. R. A. (2013). The relationship of reading strategies and self-efficacy with the reading comprehension of high school students in Indonesia. (Doctoral dissertation). Retrieved from Proquest Dissertations and Theses Global. (UMI No. 356735)

Ülper, H., Yayli, D., \& Karakaya, İ. (2013). Developing the Reader Self-Efficacy Scale. Ahi Evran University Kirşehir Faculty of Education Journal, 14(1), 85-100. 